\title{
MICROCLIMATE MONITORING OF POZALAGUA CAVE (VIZCAYA, SPAIN): APPLICATION TO MANAGEMENT AND PROTECTION OF SHOW CAVES
}

\author{
Javier Lario ${ }^{1}$ And Vincente SoleR ${ }^{2}$
}

\begin{abstract}
This paper reports the results of a continuous monitoring program carried out in Pozalagua show cave (Vizcaya, Spain) between April 2001 and June 2004. The study focused on understanding the variations in the microclimatic parameters inside the cave to assess the effect of visitors and to design a visitor regime to minimize impact and optimize its carrying capacity. The main parameters susceptible to variations due to a massive influx of visitors are the internal temperature of the cave and the concentration of $\mathrm{CO}_{2}$ in the cave air. Proposed management measures focus on reducing the humaninduced variations of both parameters.
\end{abstract}

\section{INTRODUCTION}

Most show caves require physical modifications to allow visitor access. These modifications change the ventilation regimen, relative humidity, air temperature, and $\mathrm{CO}_{2}$ in the cave environment (Hoyos et al., 1998; Pulido-Bosch et al., 1997; Fernández-Cortés et al., 2006a; Russel and MacLean, 2008). For example, increased condensation from respiration has been shown to cause a decline in air quality leading to degradation of speleothems (Pulido-Bosch et al., 1997; Sarbu and Lascu, 1997; Baker and Genty, 1998; Sanchez-Moral et al., 1999; FernándezCortés et al., 2006a, 2006b; Russell and MacLean, 2008). As has been pointed out by Russel and MacLean (2008), the effect of increased $\mathrm{CO}_{2}$ exhaled by cave visitors is another parameter that has a major impact on show caves (Huppert et al., 1993; Gillieson, 1996; de Freitas, 1998; de Freitas and Banbury, 1999), since levels of $\mathrm{CO}_{2}$ above $2400 \mathrm{ppm}$ can potentially increase the deterioration of speleothems, and levels above $5000 \mathrm{ppm}$ can be dangerous to humans (Kermode, 1979).

This paper presents the results of a continuous monitoring program carried out in Cueva de Pozalagua show cave between April 2001 and June 2004. The study focused on understanding the variations of the microclimatic parameters inside the cave to evaluate the effect of visitors, and on developing an optimum visitor regime to minimize the effect of those visitors on the cave by optimizing its carrying capacity. Previous results recorded for one year (2001-2002) were presented in Lario et al. (2005).

Any tourist area must consider the carrying capacity of the overall resource as essential to management of the environment (Cigna, 1993; Huppert at al., 1993; Hoyos et al.,1998; Mangin et al., 1999; Calaforra et al., 2003; Fernández-Cortés et al., 2006b), but some authors have also pointed out the difficulties of quantifying the carrying capacity, given the large number of variables involved and the subjectivity of some of these (Middaugh, 1977;
Hammitt and Cole, 1987; Hoyos et al., 1998). In evaluating this capacity, the challenge lies in quantifying the acceptable limit for changes in a parameter in the karstic environment. The carrying capacity can be defined as the maximum number of visitors per unit of time that will maintain a critical factor or parameter within defined, natural limits. The parameter most susceptible to change will be the critical factor in calculating visitor capacity (Cigna, 1993; Hoyos et al., 1998).

Ideally, this type of study should begin with the installation of instrumentation to perform background monitoring of the cave prior to any alteration in the natural conditions and before any tourist activity. Almost one year of microenvironmental recording without human disturbance would be required (Sanchez-Moral et al., 1999; Michie, 2005). In this case, the study was initiated after some years of tourist activity and after some human modifications to the cave's natural environment, including the opening of the current entrance using explosives and the closing of two natural entrances to control access to the cave. It is, therefore, very difficult to establish the natural conditions of the cave prior to human visits. Consequently, in this study we use a relative background, which means the least-modified microclimate conditions due to tourism activity. This study only focuses on cave management as it is related to the effect of visitors on the cave's microclimate. Any other impact related to tourist activity in the cave has not been considered.

\section{Location and Geological Setting}

Cueva de Pozalagua is located in the western part of the province of Biscay, northern Spain (Fig. 1) and is geologically located on the southern flank of the Carranza anticline, which is mainly made up of Urgonian limestone

\footnotetext{
${ }^{1}$ Facultad de Ciencias, Universidad Nacional de Educación a Distancia - UNED, Senda del Rey, 9, 28040 Madrid, Spain, javier.lario@ccia.uned.es

${ }^{2}$ Instituto de Productos Naturales y Agrobiología, CSIC. Avda.Astrofísico Fco. Sánchez, La Laguna, 38206 Tenerife, Spain
} 


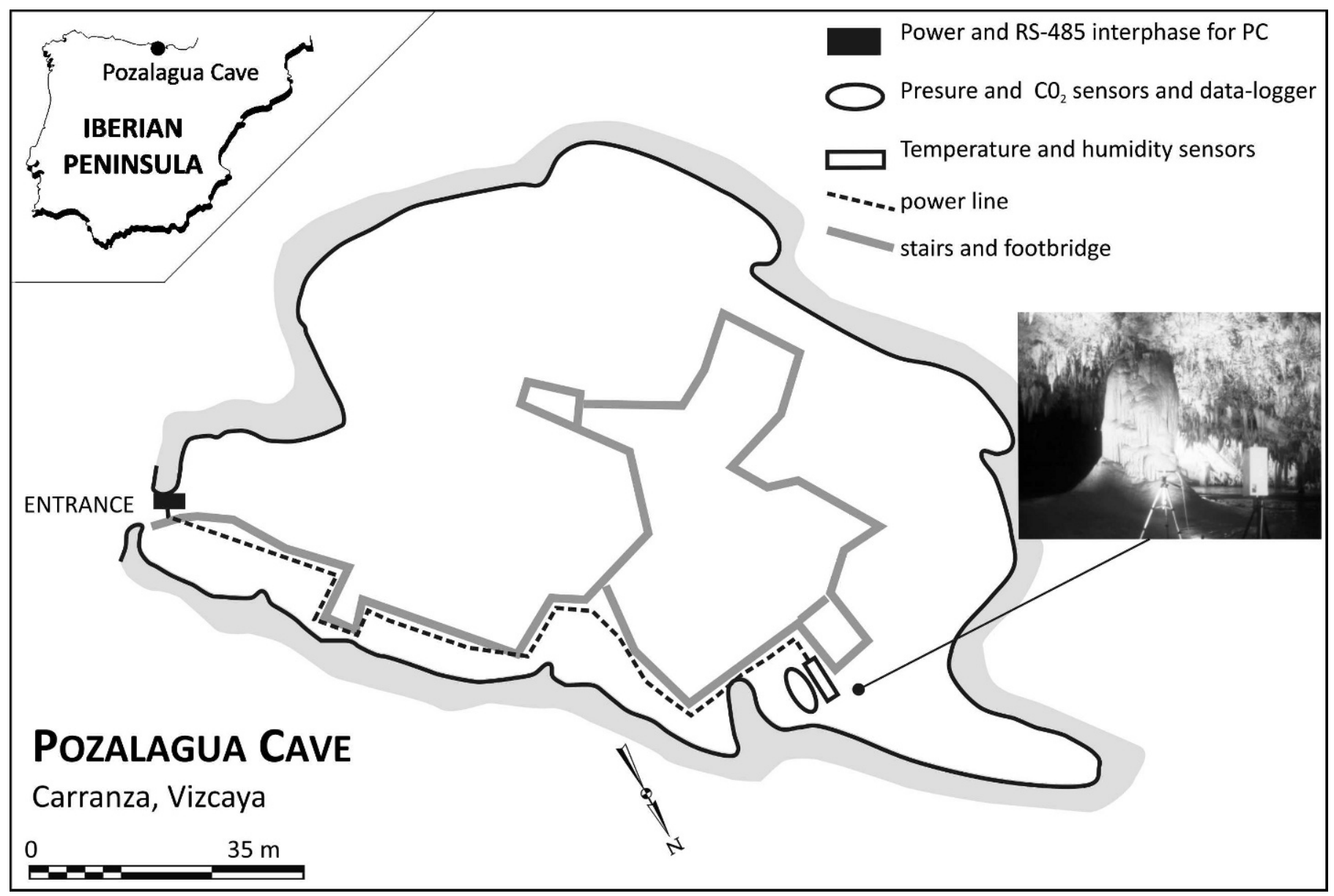

Figure 1. Location and plan map of Cueva de Pozalagua.

(IGME, 1978). The cave is part of a larger karstic system with an area of $15 \mathrm{~km}^{2}$ (Ugarte, 1989).

The limestones that make up the Carranza karstic system have different compositions and textures, corresponding to a large extent to reef and para-reef limestones of the Urgonian facies (Jurassic-Cretaceous transition). These appear in great banks of massive or diffuse stratification, with approximately 1 -m-thick individual white and black limestone layers, accompanied by breccias. In the fracture zones are irregular strips of calcification and dolomitization generated by the circulation of hydrothermal fluids. The limestone dips gently $\left(15^{\circ}\right.$ to $\left.20^{\circ}\right)$ towards the southeast, and the dip is above $30^{\circ}$ in some places in the fault zones. In the case of Pozalagua, the cave developed at the limestone and the dolomite contact generated by a fault striking $\mathrm{N} 145^{\circ} \mathrm{E}$ where hydrothermal fluids have circulated.

Cueva de Pozalagua consists of a main chamber $125 \mathrm{~m}$ in length, $70 \mathrm{~m}$ in width, and $12 \mathrm{~m}$ of height (Fig. 1). The cave, due to the profusion of several phases of speleothems and the collapse of blocks, displays two levels with a difference of 4 to $5 \mathrm{~m}$ between them. At the present time, the entrance has a metal door and metal stairs descending $3 \mathrm{~m}$. The public route through the cave is covered with a metal grid and a footbridge to the sides. Illumination is varied, with a system of cool-lights and warm-lights. The most attractive feature of the cavity is the large amount of eccentric stalactites (also called helictites).

\section{Methods: Monitoring The Microenvironmental Parameters}

Research was carried out by a consulting company in collaboration with the Carranza council. It is based on an 8-channel, 16-bit data acquisition system (DAS), with storage capacity for 32,000 measurements. The system was equipped with a battery to sustain its operation for short periods of time (6 to 7 days) in case of power outages. In addition, a visual alarm system was set up to facilitate detection by workers in the cave of a possible failure in the DAS.

A set of sensors and signal-conditioning units was used:

- Air temperature sensor (T) with a Pt100, measurement range between $0-50{ }^{\circ} \mathrm{C}$ with a resolution of $0.01{ }^{\circ} \mathrm{C}$.

- $\mathrm{CO}_{2}$ sensor based on non-dispersive spectrometry with infrared radiation, double beam, $1 \mathrm{ppm}$ resolution and 0-7000 ppm measurement range. 
- Capacitive-type relative-humidity sensors with a $0-100 \%$ measurement range and a resolution of $0.1 \%$.

- Atmospheric-pressure sensor with a silicon-diaphragm detector temperature balanced, barometric range and $0.1 \mathrm{hPa}(0.1 \mathrm{mbar})$ resolution.

- The ${ }^{222} \mathrm{Rn}$ concentration was measured by means of a Pylon AB5 scintillometer with a continuous passive radon detector (CPRD). This equipment was calibrated periodically with a ${ }^{222} \mathrm{Rn}$ calibration standard cell model Pylon 3150 and RNC standard radioactive sources of known activity concentration (Chau et al., 2005). An automatic recording system was programmed to store records every hour.

The system was completed by a stabilized power supply, located at the entrance of the cave, with regulated outputs of $+24 \mathrm{~V},+12 \mathrm{~V}$, and $-12 \mathrm{~V}$ and load tension of the back-up battery. This power source included surge protectors in case of spikes produced in the power line by atmospheric storms.

Sensors and DSA were situated in the Versalles Chamber, where the largest number of helicites and other spelothems are located and where visitors stop for periods of 10 to 15 minutes. Data points were recorded every 10 minutes.

Transmission of data to the cave entrance was by means of a low-voltage line and an RS485 interface. An RS485/ RS232 converter was used to communicate from a personal computer to the DAS. In this way, all routine operations of unloading data, verification of the sensors, and starting the equipment were controlled from outside the cave. The locations of the different elements of the measurement system are detailed in Figure 1.

\section{Microenvironmental Parameters Record AND RESULTS}

Microenvironmental parameters were measured inside the cave from April 1, 2001, to June 30, 2004, with an interval of either 10 or 20 minutes; the recording interval was changed during the different seasons to reflect different tour frequencies. Because of failures in the electric system or sensors, some gaps in the record were supplied by means of measurements taken with portable instruments. We used the weather dataset provided by the Basque Meteorology Service (station G065 Cerroja-Karrantza, Bizkaia) located at an altitude of $677 \mathrm{~m}$ for the climatic parameters outside the cave.

\section{Management of the Cave}

There was no limit to the number of visitors inside the cave during the entire recording period. When possible, each group did not exceed 30 people, although this number increased greatly during holiday periods and on bank holidays. The visiting hours are 11 a.m. to 5 p.m. during winter and 10 a.m. to 7 p.m. during summer. On Mondays, the cave is closed to the public, except during holiday periods or on bank holidays.

Each group of visitors spends between 40 and 50 minutes inside the cave. There is a break of about 10 minutes between groups, but not if it is a busy day. The door is opened only for the entrance and exit of visitors and remains closed during the visit. Lights are always on during open hours.

The number of visitors during the recorded period was 151,315 , with a peak of 1,389 visitors on one day and an average of 170 visitors per day. The daily number of visitors was recorded by the cave guides at our request. The results obtained on the variations in the microenvironmental parameters of the cave during the period studied, together with the outside climatic parameters, are shown in Figure 2.

\section{Relative Humidity of the Air}

The relative humidity in the cave is always over $97 \%$, very close to saturation. This is characteristic of an underground environment and common inside caves. In this case, the saturated state is favored by the fact that thermal oscillations inside the cave are very small. In addition, there is water present in the cave. Because of the little variation, the data are not displayed in any of the figures.

\section{Atmospheric Pressure}

Atmospheric pressure inside the cave is very close to that outside. The average pressure inside the cave is $979 \mathrm{hPa}$, with a maximum of $998 \mathrm{hPa}$ and a minimum of $949 \mathrm{hPa}$. During the recorded period there were stable periods during summer and the beginning of winter and variable periods at the end of winter and during spring, as well as at the beginning of autumn.

\section{Air Cave and Outdoor Temperature}

Mean air cave temperature (internal temperature, $T_{\text {int }}$ ) during the studied period was $12.96{ }^{\circ} \mathrm{C}$ but increased since the beginning of the study, most likely due to the massive numbers of visitors entering the cave. As Figure 2 shows, the underground temperature is influenced by the outdoor cycle, but with a time lag due to the low thermal conductivity of the rock. Inside the cave, there are two well-differentiated periods: six months of thermal rise (from May to October) and six months of thermal fall (from November to April). The minimum temperature recorded was $12.78{ }^{\circ} \mathrm{C}$, and the maximum was $13.39{ }^{\circ} \mathrm{C}$, which coincided with a very large number of visitors during October 2002. Therefore, the annual temperature inside the cave fluctuates about 0.5 to $0.6{ }^{\circ} \mathrm{C}$, including the effect of visitors. It is difficult to calculate the effect of visitors in detail, because there is no record of temperatures before the cave was opened to tourism, but, even so, we selected a period with the maximum temperature inside the cave (October-November), and using temperatures taken during 

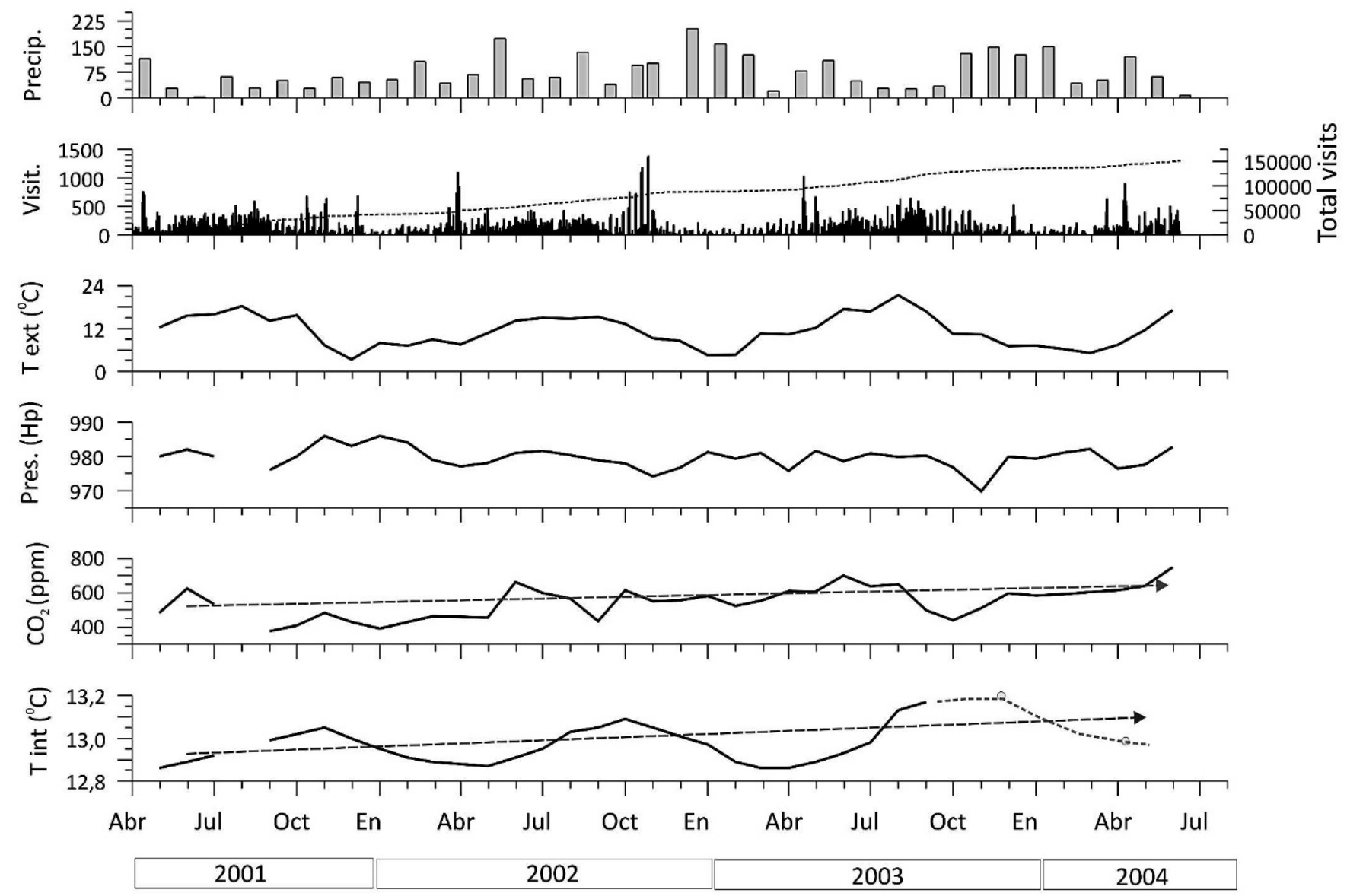

Figure 2. Microclimatic data from 2001 to 2004 (monthly averages except visitor numbers).

the night and during periods without visitors, we estimate that the annual temperature range, without the effect of visitors (relative background), would be 0.25 to $0.30{ }^{\circ} \mathrm{C}$. By means of the same procedure, we calculated that maximum temperature inside the cave without the cumulative influence of visitors would be less than $13.05{ }^{\circ} \mathrm{C}$. That value is surpassed on multiple occasions due to the influx of visitors.

Also, the occurrence of high numbers of visitors during the Easter holidays, just when the cave should reach its natural minimum temperature, provokes a break in the natural trend. A similar effect can be shown during the maximum annual temperature period, in October-November, again coinciding with an increase of visitors on bank holidays.

Using linear regression during a complete annual recording period (April 2001 to April 2002), we estimate that the mean temperature of the cave increases by $0.04^{\circ} \mathrm{C} / \mathrm{yr}$, which was confirmed by the data of the following years. This phenomenon will be detrimental to the cave and should be taken into account in its management.
The mean outdoor temperature (external temperature, $T_{\text {ext }}$ ) was $11.44{ }^{\circ} \mathrm{C}$, with a minimum of $-6.3{ }^{\circ} \mathrm{C}$ and a maximum of $37.1{ }^{\circ} \mathrm{C}$ during the recording period. The mean is lower than the mean cave temperature mainly because $T_{\text {int }}$ is not the natural one but is modified by visitors.

\section{Changes IN $T_{\text {int }}$}

In order to evaluate the effect of visitors on the daily record of microenvironmental parameters, a period with both low (nil) and high ( $>250$ visitors/day) numbers of visitors was chosen. Figure 3 shows the period June 3-8, 2001. Variation in $T_{\text {ext }}$ is low because there is a stable situation, with a maximum during midday and a minimum late at night.

During visit days there is an overall rise in $T_{i n t}$, which also reflects each group of visitors entering the cave. The maximum increase recorded is $0.21{ }^{\circ} \mathrm{C}$ on June 3 , which amounts to $84 \%$ of the natural annual variation $\left(0.25{ }^{\circ} \mathrm{C}\right)$. Recovery to the temperature previous to visits took about $12 \mathrm{~h} 15 \mathrm{~min}$, similar to that of June 5 (12 h $45 \mathrm{~min}$ ). These 

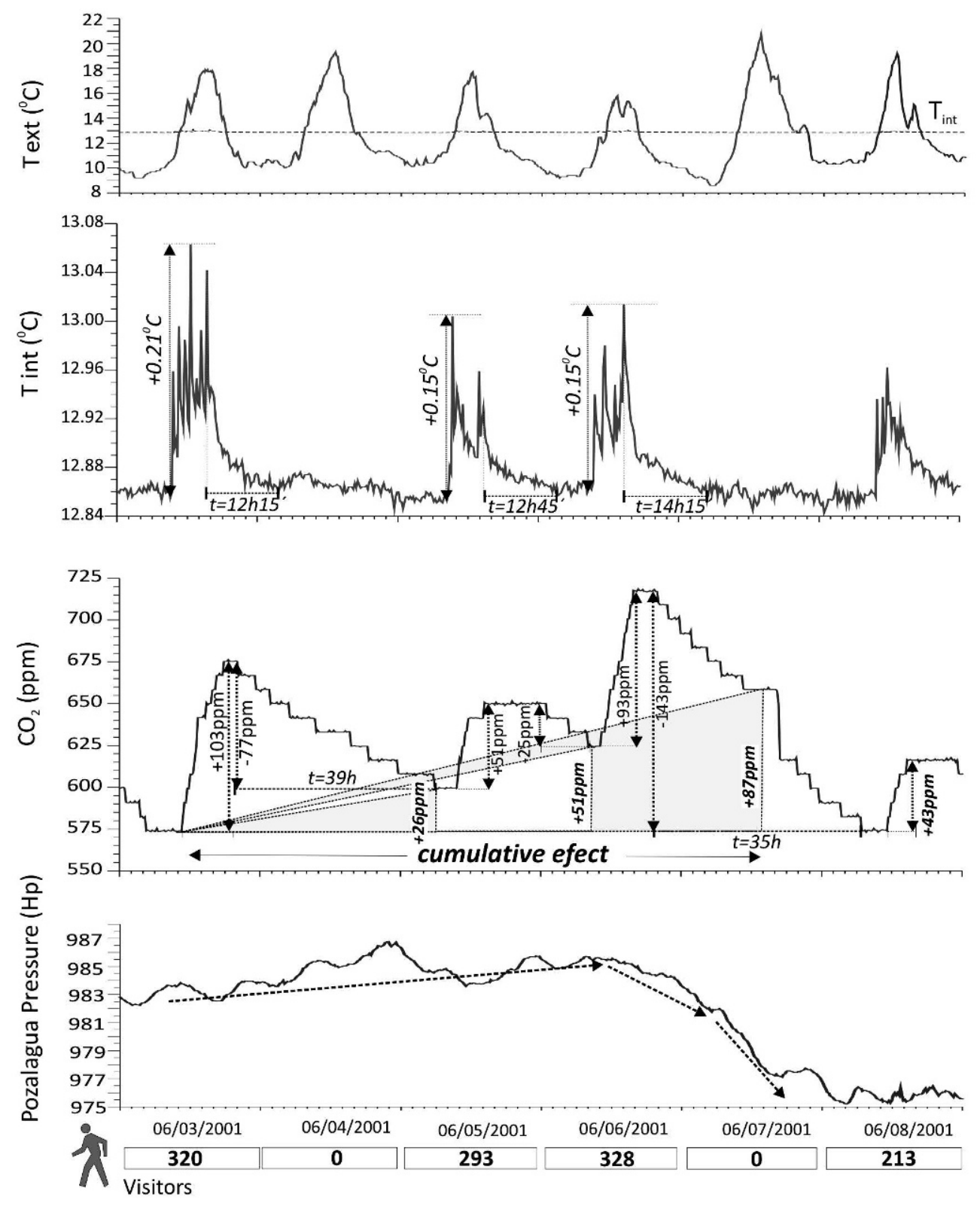

Figure 3. Evolution of main microclimate parameters during heavy use of the cave (June 2001).

values are considered the typical $T_{\text {int }}$ recovery time after a visit day during most of the year. The next day (June 6) the recovery time was slightly longer (14 h $15 \mathrm{~min})$, showing a possible cumulative effect of days with large numbers of visitors.

\section{$\mathrm{CO}_{2}$}

The mean annual concentration of $\mathrm{CO}_{2}$ recorded inside the cave was $570 \mathrm{ppm}$, with a minimum of $325 \mathrm{ppm}$ and a maximum of $1060 \mathrm{ppm}$, corresponding to a massive influx of visitors. The presence of only thin soil cover above the cave is likely to be the cause of these low values, as the soil is largely responsible for the total dissolved $\mathrm{CO}_{2}$ in the vadose zone (Baldini et al., 2006). The evolution of $\mathrm{CO}_{2}$ over a year-long period shows that the cave is the upper part of a deep karstic system. Periods with higher natural concentration of $\mathrm{CO}_{2}$ are related to a rise in $T_{\text {ext }}$, and occur once it is above $T_{\text {int }}$ and remains there. Using the same methodology as for $T_{\text {int }}$, it is possible to estimate that the maximum value in semi-natural conditions (relative back- 
ground) would be lower than $600 \mathrm{ppm}$, giving an annual natural variation of $300 \mathrm{ppm}$.

\section{Changes IN $\mathrm{CO}_{2}$}

During massive influxes of visitors (holiday periods and bank holidays), a significant increase in $\mathrm{CO}_{2}$ levels, with slow recovery to previous levels, is produced (Fig. 2). We used the period between June 3 and 8, 2001, to evaluate $\mathrm{CO}_{2}$ levels during periods with no visitors and days with large number of visitors (Fig. 3). Visits by 290 to 300 people per day provoked an increase of 50 to $100 \mathrm{ppm}$ of $\mathrm{CO}_{2}$ in the cave environment. Recovery to previous levels before the entry of visitors was not completed during the daily cycle, but continued during the next day because there were no visitors on June 4, for a total recovery of $75 \%$ in $39 \mathrm{~h}$. On June 5 the recovery ceased because there were almost 300 visitors. Finally, during a day without any visits (June 7), total recovery of previous $\mathrm{CO}_{2}$ levels was reached after $35 \mathrm{~h}$.

Drops in $\mathrm{CO}_{2}$ concentration are also related to atmospheric pressure variations. During June 6 and 7 there was an abrupt fall in external atmospheric pressure that favored cave ventilation. This probably accounts for the quick and full recovery after the visitors of June 6 . During stable weather, the $\mathrm{CO}_{2}$ concentration does not recover fully between visitor days, as on June 3 and 4 .

\section{The Effect of Busy Periods on}

\section{Microenvironmental Parameters: Easter}

\section{Holidays 2002}

To check the effect of busy holiday periods on the microenvironmental parameters inside the cave, the 2002 Easter holiday was studied in detail (Fig. 4). Between March 28 and April 1, 2002, there were 3574 visitors, with a maximum of 1100 visitors on Good Friday. The increase in $T_{\text {int }}$ during the maximum influxes of visitors (always over 600 visitors/day) ranges from 0.16 to $0.23{ }^{\circ} \mathrm{C}(65 \%$ to $92 \%$ of the natural annual variation). These largest daily $T_{\text {int }}$ increases also provoke an increase in the recovery time from approximately $12 \mathrm{~h}$ seen in Figure 3. So, during the four days of heavy visits, there was an accumulated $T_{i n t}$ increase after each day of 0.05 to $0.07^{\circ} \mathrm{C}$ ( 20 to $28 \%$ of annual range), and it took $72 \mathrm{~h}$ during days with few or no visits for the temperature to fully recover. This cumulative warming effect could also be partly related to the increase in $T_{\text {ext }}$, because the cave door was open during the entrance and exit of visitors. From March 28 to March 31 there was an increase in minimum $T_{\text {ext }}$ of $6{ }^{\circ} \mathrm{C}$. Nevertheless, the effect is offset by the natural cooling trend in the cave during this season, and also because of the $T_{\text {ext }}$ fall of $8{ }^{\circ} \mathrm{C}$ during the following two days. Busy days will cause greater warming inside the cave if there is also a warming trend outside the cave.

These changes can also be observed in the $\mathrm{CO}_{2}$ record. The direct daily increase varies between 185 and $280 \mathrm{ppm}$. The rest period of $16 \mathrm{~h}$ between the closing of the cave and the next day's opening is not enough for recovery to the levels prior to the visits. Actually, much more time is needed (nearly 35 h; see Fig. 2). Because there is not enough time to recover original $\mathrm{CO}_{2}$ levels between visits, the total $\mathrm{CO}_{2}$ cumulative effect is nearly $400 \mathrm{ppm}$, more than doubling the values registered previous to the large numbers of visitors at Easter.

This example confirms that the cave atmosphere needs a much longer time to return to previous $\mathrm{CO}_{2}$ values after heavy use than is needed for temperature recovery. The total time with high visitor influence is the same (ca. $95 \mathrm{~h}$ ) for both, but overall about $118 \mathrm{~h}$ is necessary to recover the original $\mathrm{CO}_{2}$ levels, while only $72 \mathrm{~h}$ are needed to return to the original $T_{\text {int }}$ values. It should also be considered that this happened during a favourable situation in which the average $T_{\text {ext }}$ was lower than $T_{\text {int }}$, and also that there was a drop in atmospheric pressure. Under different circumstances the recovery time would probably be longer.

Another impressive data set can be seen in Figure 5, which shows the period for August 2003. During this time, there were 11,981 visitors to the cave. Using the same methodology and focusing only on the cumulative increase in minimum daily $T_{i n t}$ during the whole month that represents nearly $75 \%$ of the annual range (Figure 2), there is an increased step in the $T_{i n t}$ record, which never reached the original level during the study period.

${ }^{222} \mathrm{RN}_{\mathrm{N}}$

The level of ${ }^{222} \mathrm{Rn}$ was measured from October 19, 2002, to January 16, 2004. Mean annual concentration of ${ }^{222} \mathrm{Rn}$ recorded inside the cave was $838 \mathrm{~Bq} \mathrm{~m}^{-3}$, with a minimum of $228 \mathrm{~Bq} \mathrm{~m}^{-3}$ and a maximum of $1568 \mathrm{~Bq} \mathrm{~m}^{-3}$. Radon levels in karstic systems depend on a complex interrelation of different factors, both external and internal (Kies et al., 1997): outside-inside temperature differences, wind velocity, atmospheric pressure variations, humidity, karstic geomorphology and porosity, and radium content in the sediments and rocks. Since ${ }^{222} \mathrm{Rn}$ is not related to human presence, it could be used as an independent indicator of cave ventilation. Low values show ventilation of the cave, while high values show a decrease in air flow inside the cave. The ${ }^{222} \mathrm{Rn}$ concentration should show a good correlation with evolution of natural $\mathrm{CO}_{2}$ values. Negative or inverse correlation is an indicator of $\mathrm{CO}_{2}$ increase due to human activity.

\section{Discussion}

Cave microclimate is controlled by external and internal factors. The alteration of cave microenvironmental conditions causes a break in the natural dynamic equilibrium of the cave system. In order to reduce visitor impact, cave managers need to understand the factors that contribute to the cave microclimate to define and maintain an appropriate range of environmental conditions for each particular cave system (Gillieson, 1996; de Freitas, 1998; 


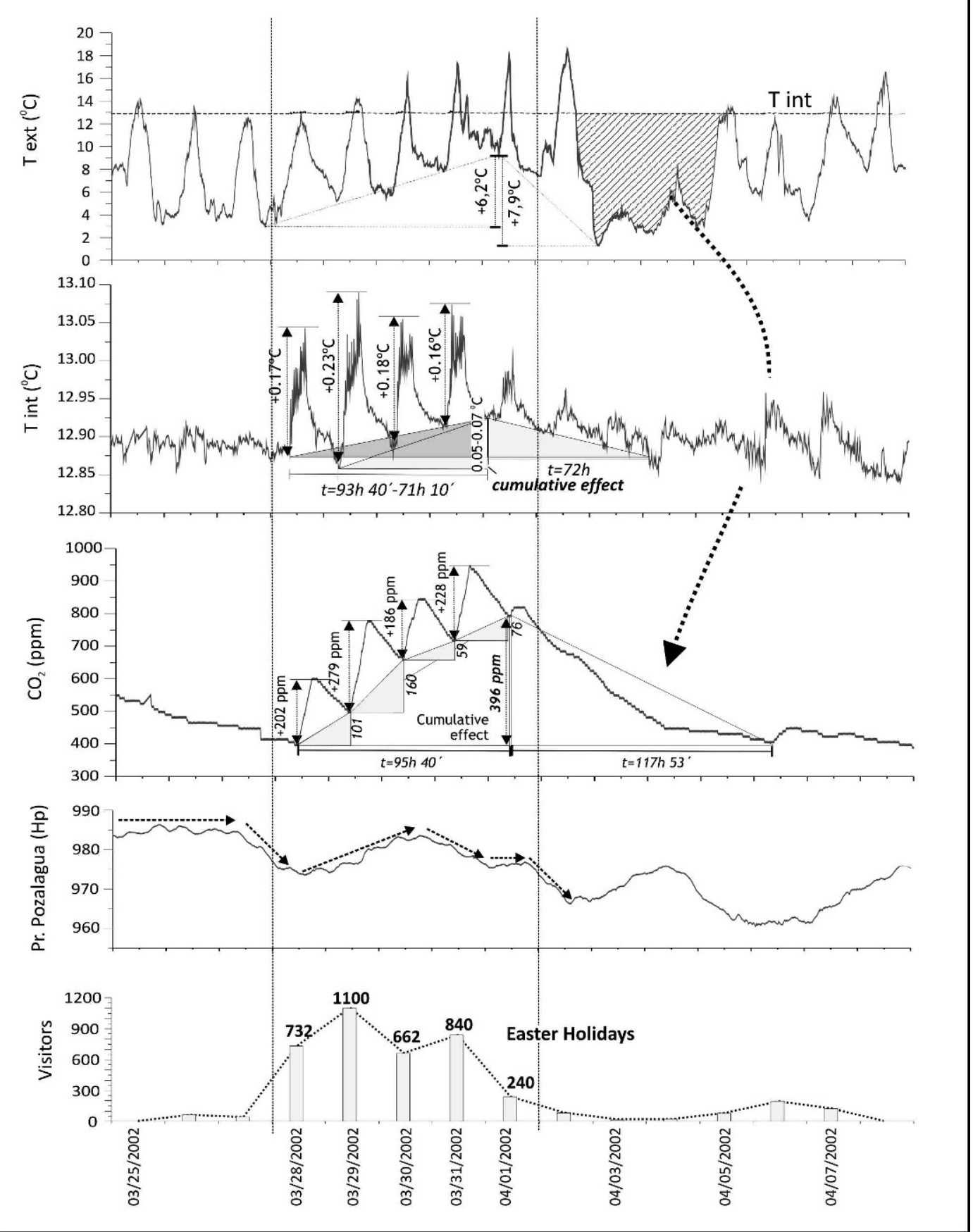

Figure 4. Evolution of main microclimate parameters during heavy use of the cave (Easter holidays 2002).

Fernández-Cortés et al., 2006b; Russel and MacLean, 2008).

Helicites growing in the cave, its greatest tourist attraction, are directly related to the occurrence of various factors (Lario et al, 2005): low water-infiltration velocities, hydrochemistry of the infiltration waters (affected by the lithology around the cave), and the physical-chemical equilibrium between the cave atmosphere and the infiltration water. This last point is the one factor affected by cave visitors causing changes to temperature, water vapor, and $\mathrm{CO}_{2}$ concentrations. All these variations affect the physical-chemical equilibrium, and are also very important for colonization by microbial communities and for corrosion of the speleothems and host rock.

From the analysis of data obtained during the study, it is possible to conclude that Cueva de Pozalagua has a low natural temperature range $\left(0.25{ }^{\circ} \mathrm{C}\right)$ compared to other shallow caves close by, such as Altamira Cave $\left(1.6{ }^{\circ} \mathrm{C}\right.$, 


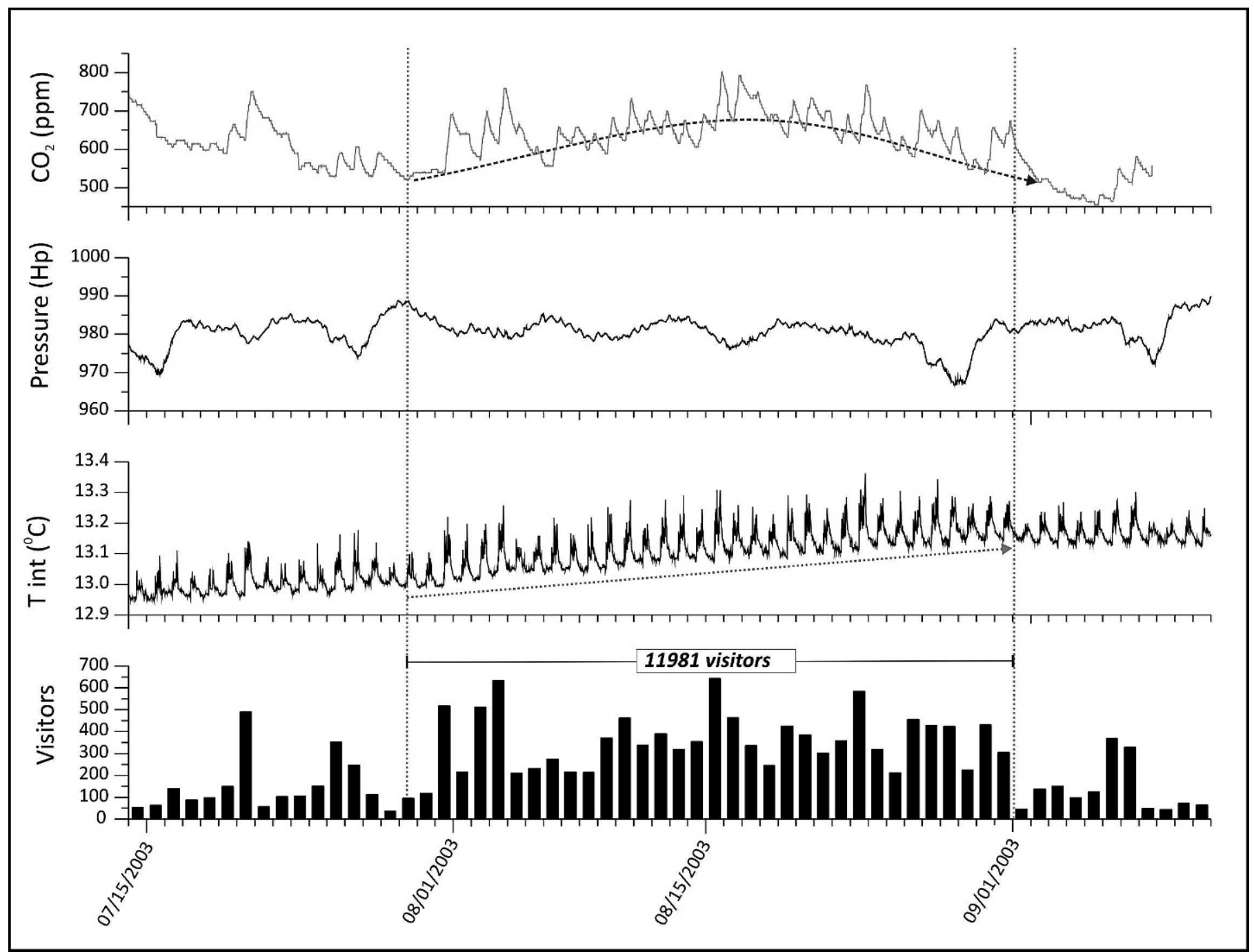

Figure 5. Evolution of main microclimate parameters during heavy use of the cave (August 2003).

Sanchez-Moral et al., 1999). Also, the average annual natural concentration of $\mathrm{CO}_{2}$ is moderate to low (448 ppm), with an annual variation range of $300 \mathrm{ppm}$. Recovery from a day of visits requires a long time $\left(12 \mathrm{~h}\right.$ for $T_{\text {int }}$ values and $35 \mathrm{~h}$ for $\mathrm{CO}_{2}$ ). These characteristics show a high degree of isolation of the cave relative to changes in external climatic conditions. In these conditions, any change inside the cave will remain and accumulate over time, modifying the fragile physical-chemical equilibrium of the system. This is confirmed by the warming trend of the cave observed during this study. Due to this special characteristic of the cave, proposals for modifying the visitor regime should focus on avoiding disrupting the equilibrium of the system. Obviously, for complete success, the best case scenario is the absence of any human influence. In order to minimize the effect of visits, it is useful to calculate the visitor carrying capacity of the cave to establish the number of visitors per day that does not irreparably deteriorate the cave.

\section{$T_{i n t}$ As A Limitation Factor}

Figure 6a shows a direct relation between daily visits and net increase in $T_{\text {int }}$ calculated during periods without cumulative effect. There is dispersion in data when there are few visitors, but there is a good correlation when the number of visitors is over 100. The dispersion of data on the days with few visits is most likely related to varying stopping times in the Versalles Chamber, while during busy days, the stopping time in the Versalles Chamber is more controlled and is the same during all visits. Therefore the correlation line obtained is useful to predict the increase in $T_{\text {int }}$ after a day of 100 to 700 visitors.

Maximum $T_{\text {int }}$ recorded in the cave without the cumulative effect of visits was lower than $13.05{ }^{\circ} \mathrm{C}$. Hence the proposed visiting regime needs to be adjusted in order not to surpass this $T_{i n t}$ and, consequently, to maintain the natural annual range. As was recorded, this $T_{\text {int }}$ was frequently surpassed, and on more occasions during October-November. From the average monthly $T_{\text {int }}$ 


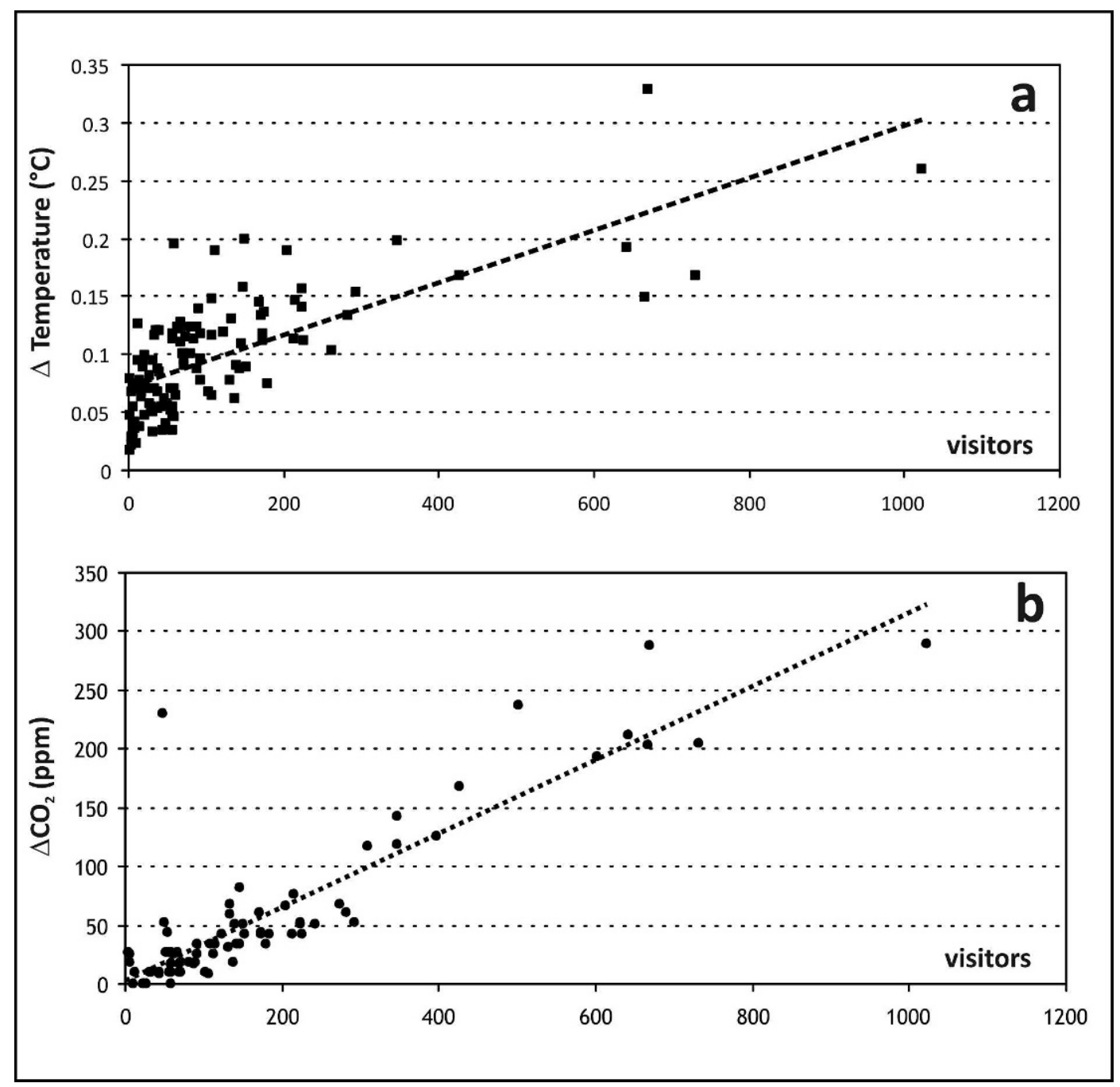

Figure 6. Relation between daily visits and net increase in $T_{\text {int }}$ (a) and $\mathrm{CO}_{2}$ concentration (b) calculated during periods without cumulative effect.

recorded, the limitation criterion is to not exceed the maximum estimated natural $T_{\text {int }}$. For example, in June, with an average $T_{i n t}$ of $12.89{ }^{\circ} \mathrm{C}$, the maximum number of visitors allowed per day is estimated at 275 . These visitors provoke an increase in $T_{i n t}$ of $0.16{ }^{\circ} \mathrm{C}$, which is the maximum allowable in order to not surpass the maximum $T_{\text {int }}$ under natural conditions. Using these criteria, it was possible to assess the recommended numbers of visitors per day during each month (Table 1).

\section{$\mathrm{CO}_{2}$ AS A Limitation FACTOR}

The maximum value of $\mathrm{CO}_{2}$ concentration inside the cave during undisturbed periods would be under $600 \mathrm{ppm}$ and the limiting criteria should not surpass these concentration levels. Figure $6 \mathrm{~b}$ shows a direct relation between daily visits and net increase in $\mathrm{CO}_{2}$ concentration calculated during periods without cumulative effect. In this case, the correlation is clearer than in the case of $T_{\text {int }}$, and the correlation line allows calculation of the $\mathrm{CO}_{2}$ concentration increase that would be produced by 100 to 1000 visitors. The proposed number of visitors per day for each month is presented in Table 2 .

\section{Combination of Both Factors: $T_{\text {int }}$ And $\mathrm{CO}_{2}$}

Table 3 was calculated combining both factors and using the most restrictive of each. The table shows the recommended maximum number of visitors per day during each month to avoid surpassing the natural capacity of the cave to return to a stable situation. Because we observed the cumulative effect of massive visits during the three years of study and we know the first period (2001-2002), we used the numbers calculated for this period because they were obtained during the stage in which the cave was less affected by visits. It must also be taken into consideration that all the microenvironmental parameters obtained were affected by the visitors themselves and that the truly undisturbed original conditions of the cave are unknown. Also, during the recording period, some building 
Table 1. Recommended maximum number of visitors/day each month using cave indoor temperature as a limiting factor.

\begin{tabular}{|c|c|c|c|}
\hline $\begin{array}{l}\text { Month- } \\
\text { Year }\end{array}$ & $\begin{array}{c}\text { Average } T_{\text {int }} \\
\left({ }^{\circ} \mathrm{C}\right)\end{array}$ & $\begin{array}{l}\text { Recommended } \\
\text { maximum } \\
\text { increase in } \mathrm{T}_{\text {int }} \\
\left({ }^{\circ} \mathrm{C}\right)^{\mathrm{a}}\end{array}$ & $\begin{array}{l}\text { Maximum } \\
\text { number of } \\
\text { visitors/day }\end{array}$ \\
\hline $05-2001$ & 12.86 & 0.19 & 362 \\
\hline 06-2001 & 12.89 & 0.16 & 282 \\
\hline 07-2001 & 12.92 & 0.13 & 214 \\
\hline 08-2001 & $\ldots$ & $\ldots$ & $\cdots$ \\
\hline 09-2001 & 12.99 & 0.06 & 24 \\
\hline $10-2001$ & 13.02 & 0.03 & 0 \\
\hline $11-2001$ & 13.05 & 0.00 & 0 \\
\hline $12-2001$ & 13.00 & 0.05 & 7 \\
\hline 01-2002 & 12.95 & 0.10 & 131 \\
\hline $02-2002$ & 12.91 & 0.14 & 224 \\
\hline 03-2002 & 12.89 & 0.16 & 271 \\
\hline 04-2002 & 12.88 & 0.17 & 305 \\
\hline $05-2002$ & 12.87 & 0.18 & 330 \\
\hline 06-2002 & 12.91 & 0.14 & 230 \\
\hline
\end{tabular}

and conditioning work was carried out in the cave and the environment (changes to the lighting system, building an interpretation center at the entrance of the cave, stabilization of the nearby quarry) without notifying the research team, so the influence of these on the microenvironmental record is not evaluated in this paper.

\section{Conclusions: Carrying Capacity and Proposal for Modification of Visitor Regime}

As previously explained, carrying capacity can be defined as the maximum number of visitors per unit of time while maintaining the critical factor or parameter
Table 2. Recommended maximum number of visitors/day each month using cave $\mathrm{CO}_{2}$ as a limiting factor.

\begin{tabular}{lccc}
\hline \multicolumn{3}{c}{$\begin{array}{c}\text { Recommended } \\
\text { maximum }\end{array}$} \\
$\begin{array}{l}\text { Month- } \\
\text { Year }\end{array}$ & $\begin{array}{c}\text { Average } \mathrm{CO}_{2} \\
(\mathrm{ppm})\end{array}$ & $\begin{array}{c}\text { Maximum } \\
\text { increase in } \mathrm{CO}_{2} \\
(\mathrm{ppm})^{\mathrm{a}}\end{array}$ & $\begin{array}{c}\text { Mumber of } \\
\text { nusitors/day }\end{array}$ \\
\hline $05-2001$ & 484 & 116 & 311 \\
$06-2001$ & 626 & 0 & 0 \\
$07-2001$ & 533 & 67 & 176 \\
$08-2001$ & $\ldots$ & $\ldots$ & $\ldots$ \\
$09-2001$ & 376 & 224 & 614 \\
$10-2001$ & 409 & 191 & 522 \\
$11-2001$ & 482 & 118 & 318 \\
$12-2001$ & 429 & 171 & 467 \\
$01-2002$ & 391 & 209 & 573 \\
$02-2002$ & 430 & 170 & 464 \\
$03-2002$ & 463 & 137 & 370 \\
$04-2002$ & 460 & 140 & 380 \\
$05-2002$ & 425 & 175 & 477 \\
$06-2002$ & 563 & 37 & 90 \\
\hline a 600 ppm-average & & & \\
b (a-4.7289/0.3567) & & &
\end{tabular}

within its natural fluctuation limits. Thus, the parameter most susceptible to change will be considered the critical factor for calculating visitor capacity (Cigna, 1993; Hoyos et al., 1998; Calaforra et al., 2003).

In our case, not only the number of visitors per day and distribution per month calculated using the limiting factors $\left(T_{\text {int }}\right.$ and $\mathrm{CO}_{2}$ ) is proposed, but also some changes in the visitor schedule would help to optimize visiting conditions, and therefore, increase the carrying capacity of the cave. These proposals are focused on reducing the increase in $\mathrm{CO}_{2}$ and $T_{\text {int }}$ values generated by visitors, and also on reducing the cumulative effect of these visits and the cave recovery time.

Table 3. Recommended maximum number of visitors/day each month.

\begin{tabular}{lccc}
\hline Month & $\begin{array}{c}\text { Critical Factor } \mathrm{T}_{\text {int }} \\
\text { Maximum number of visitors/day }\end{array}$ & $\begin{array}{c}\text { Critical Factor } \mathrm{CO}_{2} \\
\text { Maximum }\end{array}$ & $\begin{array}{c}\text { Combination of both critical factors } \\
\text { number of visitors/day }\end{array}$ \\
\hline January & 131 & 573 & 131 \\
February & 224 & 464 & 224 \\
March & 271 & 370 & 271 \\
April & 305 & 380 & 305 \\
May & 330 & 477 & 330 \\
June & 230 & 90 & 90 \\
July & 214 & 176 & 176 \\
August & Notam & Do Data & $\ldots$ \\
September & 24 & 614 & 24 \\
October & 0 & 522 & 0 \\
November & 0 & 318 & 0 \\
December & 7 & 467 & 7 \\
\hline
\end{tabular}


Table 4. Proposed visitors regime (carrying capacity).

\begin{tabular}{lc}
\hline Month & Maximum number of visitors/day \\
\hline January & 125 \\
February & 225 \\
March & 275 \\
April & 300 \\
May & 330 \\
June & 90 \\
July & 175 \\
August & 50 \\
September & 50 \\
October & 0 \\
November & 0 \\
December & 50 \\
\hline
\end{tabular}

After adjusting values of Table 3, the recommendations for modifying visit management are:

- Reduce the visit time inside the cave to a maximum of 30 minutes with a minimum waiting time between visits of 30 minutes. Due to the dimensions of cave passages and corridors, the ideal group of visitors should not exceed 25 to 30 people per visit.

- Close the cave weekly. Every week the cave requires almost one day without visits. Closing of the cave one day per week during normal weeks, and two days after periods with large numbers of visitors, should be rigorously observed.

- Control of the proposed maximum number of visitors per day during each month (Table 4). Closing the cave after the summer (October-November) or, if this is not possible, opening only during weekends and not exceeding 100 visitors per day.

- Shut down the lighting system between groups of visitors. Change the lighting system from "all-on" to a "partial" lighting system controlled by the cave guides.

Since, as we have explained, the original undisturbed microenvironmental levels of the cave have not been recorded, the carrying capacity should be interpreted as a changing parameter that needs to be adjusted depending on the response of the cave to the visit regime proposed. Once the measures proposed take effect and the current cumulative effect decreases, a further record of the evolution of the microenvironmental parameters would permit adjustment of the visitor regime and optimization to minimize the effect of visitors on the cave.

\section{Aknowledgements}

Thanks to the Carranza Council and the guides of the cave. This is a contribution to IGCP Project 513, Global Study of Karst Aquifers and Water Resources.

\section{REFERENCES}

Baker, A., and Genty, A., 1998, Environmental pressures on conserving cave speleothems: effects of changing surface land use and increased cave tourism: Journal of Environmental Management, v. 53, p. $165-175$.

Baldini, J.U.L., Baldini, L.M., McDermott, F., and Clipson, N., 2006, Carbon dioxide sources, sinks, and spatial variability in shallow temperate zone caves: Evidence from Ballynamintra Cave, Ireland: Journal of Cave and Karst Studies, v. 68, no. 1, p. 4-11.

Calaforra, J.M., Fernandez-Cortés, A., Sanchez-Martos, F., Gisbert, J., and Pulido-Bosch, A., 2003, Environmental control for determining human impact and permanent visitor capacity in a potential show cave before tourist use: Environmental Conservation, v. 30, no. 2, p. $160-167$

Chau, N.D., Chruściel, E., and Prokólski, L., 2005, Factors controlling measurements of radon mass exhalation rate: Journal of Environmental Radioactivity, v. 82, p. 363-369.

Cigna, A., 1993, Environmental management of tourist caves: the examples of Grotta di Castellana and Grotta Grande del Vento, Italy: Environmental Geology, v. 21, p. 173-180.

de Freitas, C.R., 1998, Cave monitoring and management: The Glowworm Cave, New Zealand, in Cave and Karst Management in Australasia XII. Proceedings of the Twelfth Australasian Conference on Cave and Karst Management, Waitomo, Carlton South, Victoria, Australasian Cave and Karst Management Association, p. 55-66.

de Freitas, C.R., and Banbury, K., 1999, Build up and diffusion of carbon dioxide in cave air in relation to visitor numbers at the Glowworm Cave, New Zealand, in Cave Management in Australasia XIII. Proceedings of the Thirteenth Australasian Conference on Cave and Karst Management, Mount Gambier, South Australia, Carlton South, Victoria, Australasian Cave and Karst Management Association, p. 84-89.

Fernández-Cortés, A., Calaforra, J.M., Jiménez-Espinosa, R., and Sánchez-Martos, F., 2006a, Geostatistical spatiotemporal analysis of air temperature as an aid to delineating thermal stability zones in a potential show cave: Implications for environmental management: Journal of Environmental Management, v. 81, p. 371-383.

Fernández-Cortés, A., Calaforra, J.M., and Sánchez-Martos, F., 2006b, Spatiotemporal analysis of air conditions as a tool for the environmental management of a show cave (Cueva del Agua, Spain): Atmospheric Environment, v. 40, p. 7378-7394.

Gillieson, D., 1996, Caves: Processes, Development, Management, Oxford, Blackwell, $324 \mathrm{p}$.

Hammitt, W., and Cole, D., 1987, Wildland Recreation: Ecology and Management, New York, John Wiley \& Sons, 341 p.

Hoyos, M., Soler, V., Cañaveras, J.C., Sánchez-Moral, S., and SanzRubio, E., 1998, Microclimatic characterization of a karstic cave: human impact on microenvironmental parameters of a prehistoric rock art cave (Candamo Cave, northern Spain): Environmental Geology, v. 33, p. 231-242.

Huppert, G., Burri, E., Forti, P., and Cigna, A., 1993, Effects of tourist development on caves and karst, in Williams, P.W., ed., Karst Terrains: Environmental Changes and Human Impact, CremlingenDestedt, Germany, Catena (supplement 25), p. 251-268.

IGME, 1978, Mapa Geológico de España, escala 1:50.000, Hoja 60, Valmaseda.

Kermode, L.O., 1979, Cave corrosion by tourists, in Cave Management in Australia 3: Proceedings of the 3rd Australian Conference on Cave Tourism and Management, Mt. Gambier, South Australia, Carlton South, Victoria, Australasian Cave and Karst Management Association, p. 97-104.

Kies, A., Massen, F., and Feider, M., 1997, Measuring radon in underground locations, in Virk, H.S., ed., Rare Gas Geochemistry, Amritsar, Punjab, Guru Nanak Dev University, p. 1-8.

Lario, J., Sánchez-Moral, S., Soler, V., Cañaveras, J.C., and Cuezva, S., 2005, Caracterización microambiental de la Cueva de Pozalagua (Vizcaya): aplicación a la gestión y protección de cavidades turísticas: Estudios Geológicos, v. 61, p. 41-59.

Mangin, A., Bourges, F., and D’Hulst, D., 1999, La conservation des grottes ornées: un problème de stabilité d'un système naturel (l'exemple de la grotte préhistorique de Gargas, Pyrénées francaises): Comptes rendús de l'Académie des Sciences de Paris, Sciences de la Terre et des Planètes, v. 328, p. 295-301. 
Michie, N.A., 2005, On the placing of objects in caves, in Cave management in Australasia 15: Proceedings of the 15th Australasian Conference on Cave and Karst Management, Chillagoe Caves and Undara Lave Tubes, North Queensland, Carlton South, Victoria, Australasian Cave and Karst Management Association, p. $51-52$.

Middaugh, G., 1977, Practical experiences with carrying capacity, in Aley, T., and Rhodes, D., eds., National Cave Management Symposium Proceedings, Mountain View, Arkansas, October 26-29, 1976: 1976, Albuquerque, Speleobooks, p. 6-8.

Pulido-Bosch, A., Martín-Rosales, W., López-Chicano, M., RodríguezNavarro, C.M., and Vallejos, A., 1997, Human impact in a tourist karstic cave (Aracena, Spain): Environmental Geology, v. 31, no. 3-4, p. $142-149$.
Russel, M.J., and MacLean, V.L., 2008, Management issues in a Tasmanian tourist cave: Potential microclimatic impacts of cave modifications: Journal of Environmental Management, v. 87, p. 474-483.

Sanchez-Moral, S., Soler, V., Cañaveras, J.C., Sanz, E., Van Grieken, R., and Gysells, K., 1999, Inorganic deterioration affecting Altamira Cave: quantitative approach to wall-corrosion (solutional etching) processes induced by visitors: Science of the Total Environment, v. 243 , p. $67-84$.

Sarbu, S.M., and Lascu, C., 1997, Condensation corrosion in Movile Cave, Romania: Journal of Cave and Karst Studies, v. 59, no. 3, p. 99-102.

Ugarte Elorza, F.M., 1989, Geomorfología de las unidades kársticas situadas en los montes vascos, in Durán, J.J., and Lopez-Martinez, J., eds., El Karst en España, Sociedad Española Geomorfología (Monorafía 4), p. 121-130. 